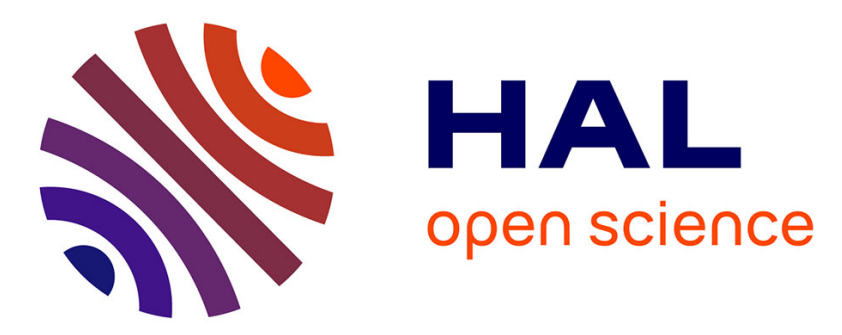

\title{
Oldest Omaliini (Coleoptera: Staphylinidae: Omaliinae) Discovered in the Opaque Cretaceous Amber of Charentes
}

David Peris, M.K. Thayer, Didier Néraudeau

\section{- To cite this version:}

David Peris, M.K. Thayer, Didier Néraudeau. Oldest Omaliini (Coleoptera: Staphylinidae: Omaliinae) Discovered in the Opaque Cretaceous Amber of Charentes. Annals of the Entomological Society of America, 2014, 107 (5), pp.902-910. 10.1603/AN14047 . insu-01070663

\section{HAL Id: insu-01070663}

https://hal-insu.archives-ouvertes.fr/insu-01070663

Submitted on 2 Oct 2014

HAL is a multi-disciplinary open access archive for the deposit and dissemination of scientific research documents, whether they are published or not. The documents may come from teaching and research institutions in France or abroad, or from public or private research centers.
L'archive ouverte pluridisciplinaire $\mathbf{H A L}$, est destinée au dépôt et à la diffusion de documents scientifiques de niveau recherche, publiés ou non, émanant des établissements d'enseignement et de recherche français ou étrangers, des laboratoires publics ou privés. 


\title{
Oldest Omaliini (Coleoptera: Staphylinidae: Omaliinae) Discovered in the Opaque Cretaceous Amber of Charentes
}

\author{
D. PERIS ${ }^{1}$ M. K. THAYER, ${ }^{2,3}$ AND D. NÉRAUDEAU ${ }^{4}$
}

\begin{abstract}
Ann. Entomol. Soc. Am. 107(5): 902-910 (2014); DOI: http://dx.doi.org/10.1603/AN14047
ABSTRACT Belonging to the Staphylinidae, the largest animal family known, recent Omaliinae are a diverse and widespread group of rove beetles. There are omaliine representatives known since Early-Middle Jurassic compressions, but members of the tribe Omaliini have been known only from the Cenozoic. Duocalcar geminum Peris and Thayer gen. et sp. nov. is described as the oldest definitive fossil of the tribe Omaliini worldwide, originating from opaque mid-Cretaceous (latest Albian) amber of Charentes, south-western France. The discovery and description were made possible with the use of the propagation phase-contrast X-ray synchrotron imaging technique, which allows the detailed study of otherwise invisible specimens in opaque amber.
\end{abstract}

\begin{abstract}
RESUMEN Appartenant aux Staphylinidae, la plus grande famille animale connue, les Omaliinae actuels constituent un groupe de scarabées très diversifié et à large répartition mondiale. Des représentants des Omaliinae sont connus depuis le Jurassique inférieur à moyen, via des fossiles en compression, mais la tribu des Omaliini n'est identifiée qu’à partir du Cénozoïque. Duocalcar geminum Peris and Thayer gen. et sp. nov. est décrit comme le plus ancien fossile connu de cette tribu, et provient de l'ambre opaque du Crétacé moyen (Albien terminal) des Charentes (Sud-Ouest de la France). Sa découverte et sa description ont été rendues possibles grâce à l'utilization des techniques d'imagerie RX synchrotron en contraste de phase, qui permettent une étude détaillée des inclusions d'insectes dans l'ambre opaque.
\end{abstract}

KEY WORDS amber, microtomography, Albian, Archingeay-Les Nouillers, south-western France

The beetle family Staphylinidae Latreille is the largest family of Coleoptera (Grebennikov and Newton 2009 ) and is considered also the largest family of any animal phylum. The family currently includes $>60,000$ described species, considering extant (99\% of the total) and extinct taxa (A. F. Newton, unpublished database, February 2014).

Omaliinae MacLeay is one of the 32 extant subfamilies recognized in Staphylinidae (Thayer 2005, Grebennikov and Newton 2009, Bouchard et al. 2011). With $>120$ extant genera in six or seven tribes, the subfamily Omaliinae is a relatively large group of rove beetles distributed worldwide (Newton et al. 2000, Thayer 2005). They are usually recognizable by the presence of a pair of ocelli near the hind margin of the head, though some genera lack or appear to lack those; well-developed prosternal and postprocoxal

\footnotetext{
${ }^{1}$ Departament d'Estratigrafia, Paleontologia i Geociències Marines; and Institut de Recerca de la Biodiversitat (IRBio), Facultat de Geologia, Universitat de Barcelona (UB), Martí i Franquès s/n, 08028 Barcelona, Spain.

2 Integrative Research Center, Field Museum of Natural History, 1400 S Lake Shore Drive, Chicago, IL 60605.

${ }^{3}$ Corresponding author, e-mail: mthayer@fieldmuseum.org.

${ }^{4}$ Université de Rennes 1, UMR CNRS 6118 Géosciences \& OSUR, 35042 Rennes cedex, France.
}

processes; and tarsal formula 5-5-5 (more detailed discussions in Newton and Thayer 1995 and Newton et al. 2000). Newton et al. (2000) additionally described Omaliinae as generally broader in body form than "typical" staphylinids, with a shorter and less flexible abdomen, and occasionally with long elytra that cover nearly the whole abdomen.

To date, 16 Mesozoic fossil species thought to belong to Omaliinae have been reported: 13 from the Jurassic and 3 from the Cretaceous (Chatzimanolis et al. 2012, Cai and Huang 2013). Although there are Omaliinae representatives dating back to EarlyMiddle Jurassic compressions (Chatzimanolis et al. 2012, and references therein), Duocalcar geminum Peris and Thayer gen. et sp. nov. is the only fossil placed in Omaliini (in the modern sense) earlier than the Cenozoic (A. F. Newton, unpublished database). In fact, the oldest Cenozoic taxa, Omalium antiquorum Wickham (Coleoptera: Staphylinidae) (USA: Colorado: Florissant Formation, Eocene) and Omalium protogaeae Heer (Coleoptera: Staphylinidae) (Croatia, Miocene) should be reexamined to determine whether they truly belong to Omalium Gravenhorst (Coleoptera: Staphylinidae) or even to Omaliini in the modern sense, in view of changes in taxonomic concepts over the last $100 \mathrm{yr}$. The omaliine record in 
amber is even scarcer: $D$. geminum is the first Omaliinae described from any amber.

Although fossils in amber can sometimes be described in more detail than compression fossils, impurities or cracks in the amber are factors that still hinder description or placement of new taxa. D. geminum was discovered in French Cretaceous amber, which is especially difficult to work with because $\approx 80 \%$ of the amber is opaque or milky (Lak et al. 2008). Fortunately, use of the propagation phase-contrast X-ray synchrotron imaging technique (PPC$\mathrm{SR} \mu \mathrm{CT}$ ) results in highly detailed 3D reconstructions of the specimens (Tafforeau et al. 2006, Lak et al. 2008, Soriano et al. 2010), allowing study of inclusions in considerable detail.

The objective of the current study is to describe a new genus and species of Omaliinae from opaque mid-Cretaceous amber of Charentes, south-western France. It is the oldest definitive member of Omaliini, which are previously known only from Cenozoic fossils.

\section{Materials and Methods}

Materials. The description of $D$. geminum is based on two specimens found in a single large piece of opaque amber (amber piece number IGR.ARC-370) that was collected in the Font-de-Benon quarry, at Archingeay-Les Nouillers, in Charente-Maritime, south-western France (for location, see Néraudeau et al. 2002, Perrichot et al. 2007).

Two amber levels are known in Archingeay (Perrichot et al. 2010): the level Alsl-A (latest Albian; Dejax and Masure 2005) is the most fossiliferous of all French Cretaceous amber-bearing strata; the level A2a (early Cenomanian; Gomez et al. 2008) contains fewer and less-fossiliferous amber pieces. The amber piece studied herein originates from level Alsl-A. Details on the geology, paleobiota, and paleoenvironment of Charentese amber deposits can be found in Néraudeau et al. (2002); Girard et al. (2009); and Perrichot et al. (2007, 2010).

Both specimens described here as the same species were found together with other arthropods embedded in the same amber piece: one Hemiptera: Fulgoromorpha, one Hymenoptera: Maimetshidae (Guyotemaimetsha enigmatica, Perrichot, Nel and Néradeau; Perrichot et al. 2011), three Hymenoptera: Scelionidae, one Psocodea: "Psocoptera," and one Blattodea.

Although Coleoptera are poorly represented in Charentes amber, with $<40$ complete specimens (V. Perrichot personal communication), D. geminum is already the eighth Coleoptera species described from French Cretaceous amber, after Paleoripiphorus deploegi Perrichot, Nel and Néraudeau and Macrosiagon ebboi Perrichot, Nel and Néraudeau (Coleoptera: Ripiphoridae); Gratshevbelus erici Soriano (Coleoptera: Belidae) (but possibly belonging to Caridae sensu Peris et al. 2014a); Synchrotronia idinineteena Soriano and Pollock (Coleoptera: Tetratomidae); Cretamerus vulloi Peris, Kolibáč and Delclòs (Coleoptera: Trogossitidae); Stephanopachys vetus Peris, Delclòs and Perrichot (Coleoptera: Bostrichidae) (incorrectly referenced as published name from 2013 instead of "in press" by Peris et al. (2014c)); and Antiquis opaque Peris, Engel, Davis and Delclòs (Coleoptera: Curculionidae) (Perrichot et al. 2004; Soriano 2009; Peris et al. 2014a,b,c; Soriano et al. 2014).

Methods. Fossils preserved in opaque amber are usually first detected using propagation phase contrast X-ray synchrotron microradiography and then threedimensionally imaged using microtomography (PPC$\mathrm{SR} \mu \mathrm{CT}$ ). This method allows the visualization of the specimens without damage to the samples; it is a noninvasive method (Tafforeau et al. 2006, Lak et al. 2008, Soriano et al. 2010).

Both specimens were imaged on the beamline ID19 at the European Synchrotron Radiation Facility (ESRF) in Grenoble, France.

The specimen IGR.ARC-370.10 (=scan A018_c) was imaged in local tomography conditions with a monochromatic beam set at an energy of $35 \mathrm{keV}$ using a Ru/B4C multilayer monochromator. To reach a sufficient level of sensitivity and details, the propagation distance was set to $40 \mathrm{~mm}$ for an isotropic voxel size of $0.678 \mu \mathrm{m}$. The detector was a FReLoN (Fast Readout Low Noise) CCD camera, coupled to a microscope system with a single crystal YAG:Ce scintillator screen $25 \mu \mathrm{m}$ in thickness. It was scanned in continuous rotation mode with the center of rotation at the center of the field of view, using 1999 projections of $0.5 \mathrm{~s}$ each over 360 degrees rotation. The rotation movement was in continuous mode to blur all the structures out of the field of view, and then to decrease their noise contribution in the reconstructed slices (Lak et al. 2008).

The specimen IGR.ARC-370.6 (= scan A018 g) was imaged with a monochromatic beam set at energy of $29.9 \mathrm{keV}$ using a multilayer monochromator. The scan was performed at a lower energy with a longer propagation distance $(150 \mathrm{~mm})$ to maximize the phase contrast effect. The detector was similar to the one used for the other specimen, but with an isotropic voxel size of $1.4 \mu \mathrm{m}$. It was scanned in continuous rotation mode with the center of rotation using 1500 projections of $0.5 \mathrm{~s}$ each.

After acquisition, the data were reconstructed using a filtered back-projection algorithm implemented in the PyHST software (ESRF, Grenoble). The residual ring artifacts were corrected on reconstructed slices with an in-house developed system. Data were then converted into 16 bits and cropped to fit with the size of the specimens. The specimens were later virtually extracted and dissected using a semimanual region growing segmentation protocol in VGStudioMax 2.1 software (Volume Graphics, Heidelberg, Germany).

We follow the family-group classification of Bouchard et al. (2011). Specific terminology for characters follows that of Newton et al. (2000) except for replacing meso- and metasternum (and -sternal) with meso- and metaventrite (and -ventral), following Lawrence et al. (2010). 


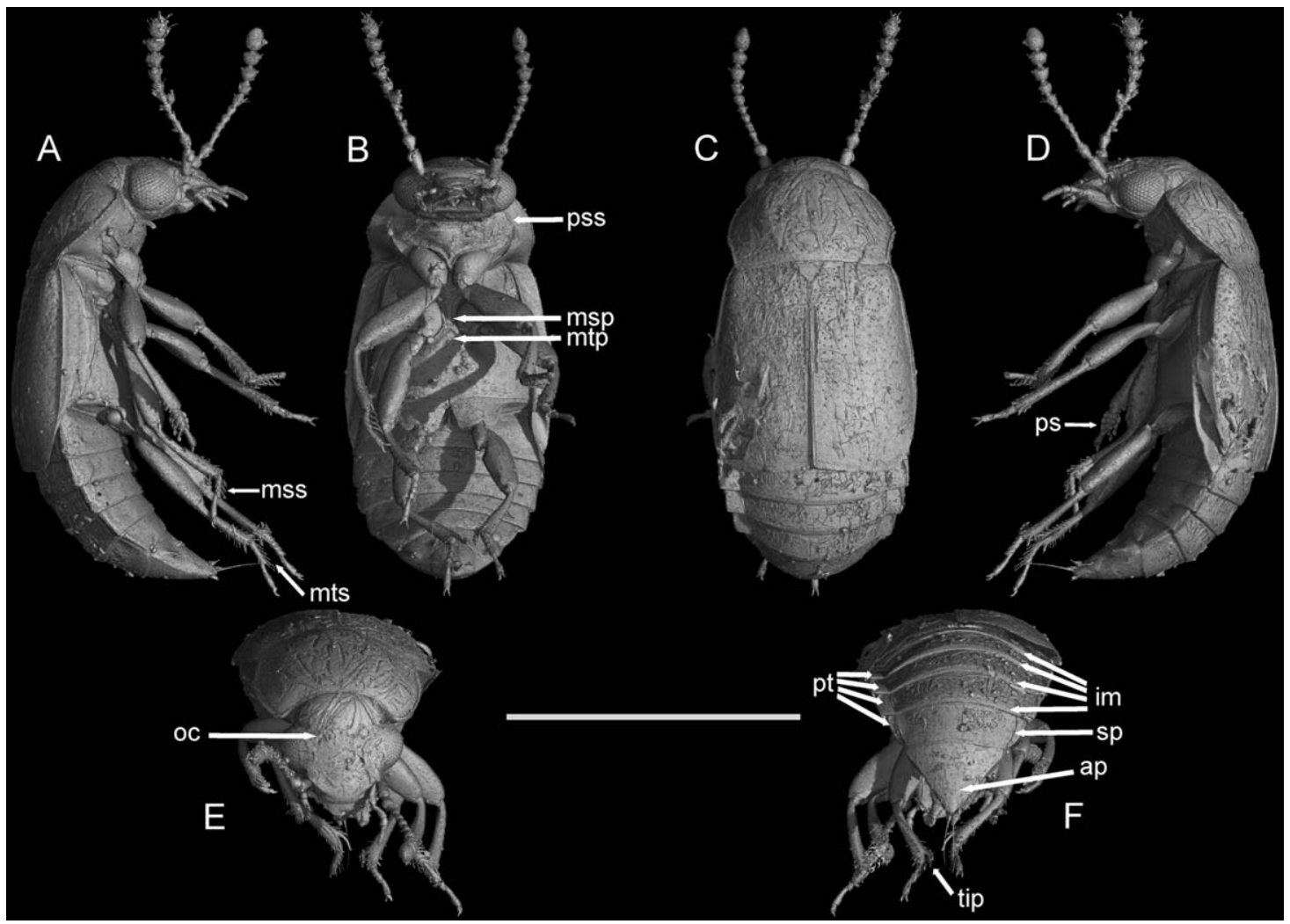

Fig. 1. D. geminum, PPC-SR $\mu$ CT reconstruction of holotype (A) right lateral; (B) ventral; (C) dorsal; (D) left lateral; (E) anterior; (F) posterior. Scale bar $=1 \mathrm{~mm}$. Abbreviations: ap, apex of tergite VIII; im, intersegmental membranes; msp, mesoventral process; mss, mesotarsal ventral setae; mtp, metaventral process; mts, metatarsal ventral setae; oc, ocellus; ps, protarsal setae; pss, pronotosternal suture; pt, paratergite; sp, spiracle VII; tip, tibial subapical projection.

\section{Systematic Palaeontology}

Family Staphylinidae Latreille

Subfamily Omaliinae MacLeay

\section{Tribe Omaliini MacLeay}

Genus Duocalcar Peris and Thayer gen. nov. (Figs. 1-4)

Type Species. Duocalcar geminum Peris and Thayer sp. nov.

Diagnosis. Body more or less oval in dorsal view and in cross-section, with elytra slightly flattened; apical maxillary palpomere about same width as preceding one; frons of head not elevated in ridge above eyes; antennomere 3 longer than antennomere 4; eyes large; ocelli seemingly present; pronotum with disc convex and punctate, margins finely crenulate; pronotal lateral margin with obtuse angle at about midpoint; elytra distinctly longer than pronotum; elytral disc with punctures arranged more or less in longitudinal rows, without impressed striae; elytra covering all of tergum III and part of tergum IV, slightly obliquely truncate at apex, forming shallow obtuse angle at suture; metatrochanter roughly triangular, with pointed api- cal projection; metatibia with long, narrow, barely tapering and slightly curved spur extending distad from subapex of inner face, surpassing tibial apex; tarsomere 5 longer than 1-4 together on each tarsus; abdominal segments III-VII each with one pair of paratergites, spiracles located near lateral margins of tergites, intersegmental membranes between segments III-VII with brick-wall pattern of sclerites; sternite IX with 2 long stout apical setae.

Description. Male. Body. Slightly flattened dorsoventrally, more or less oval in dorsal view and in cross-section; sides parallel along base of pronotum and elytra, convergent along abdomen. Dorsal surface with scattered fine setae and punctures.

Head. Narrower than pronotum, roughly triangular in front of neck, distinctly but not sharply constricted behind eyes. Eyes large, protruding laterally. One ocellus discernible (on right side) in some reconstructions (Fig. 1E, 4B-C, F). Maxillary palp with 4 palpomeres of roughly similar width, labial palp with 3 palpomeres of similar width; gular sutures well-separated, closest at middle, divergent anteriorly and posteriorly. Antenna inserted laterally under clypeus, between eye and mandible, with 11 antennomeres, apical 5 forming gradual loose club. 


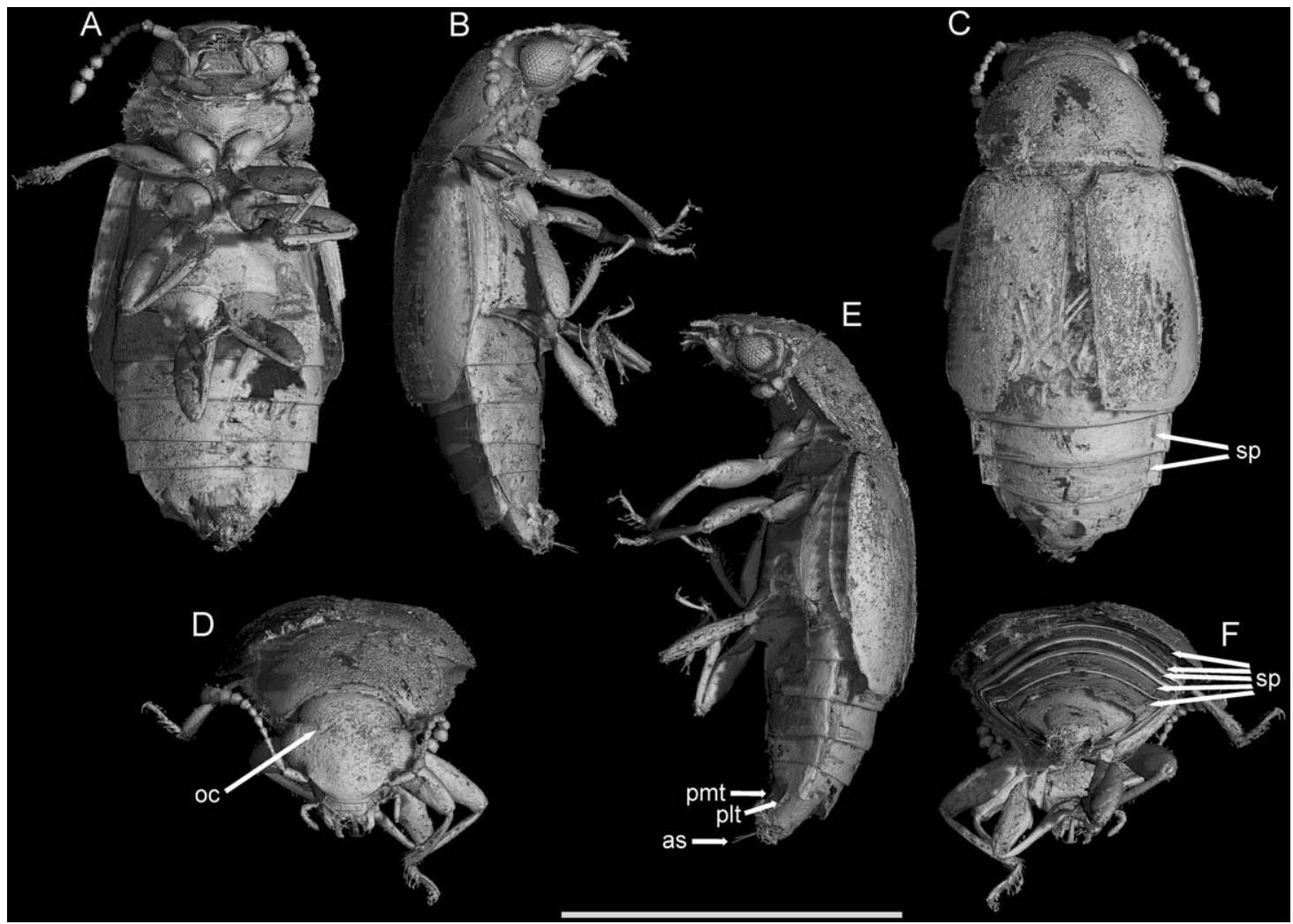

Fig. 2. D. geminum, PPC-SR $\mu \mathrm{CT}$ reconstruction of paratype (A) ventral; (B) right lateral; (C) dorsal; (D) anterior; (E) left lateral; (F) posterior. Scale bar $=1 \mathrm{~mm}$. Abbreviations: as, sternite IX apical setae; oc, ocellus; plt, sternite VIII posterolateral tooth; pmt, sternite VIII paramedian tooth; sp, spiracles III-VII.

Prothorax. Transverse, pronotal disk convex, finely and randomly punctate, with sparse setae; lateral pronotal margin carinate. Scutellum large, triangular, acute apically. Elytra truncate, exposing 5 abdominal tergites (plus genital segment); elytra moderately convex, disc slightly flattened, with rows of fine punctures. Procoxae large, oblique, slightly separated, protrochantins exposed, prosternal process extending partway between them. Mesoventrite coarsely sculptured, impunctate; mesocoxae large, slightly oblique, more or less oval, slightly elongate laterally and apically, protruding slightly, well separated by overlapping meso- and metaventral processes. Metaventrite finely and sparsely punctate, indistinctly microsculptured, lateral margins divergent posteriorly; metacoxae contiguous, transverse, extending laterally, reaching elytra; metacoxal-metaventral suture only slightly evident; apical part of metacoxae protruding ventral to abdominal sternite III.

Legs. Pro- and mesotrochanters trapezoidal, metatrochanters more elongate, with pointed apical projection; femora attached obliquely to trochanters, and somewhat compressed; all tibiae with scattered stout setae or spines in apical half to two-thirds, apex with ring of two sizes of spines; metatibia with long, narrow, and slightly hooked subapical spur extending distad beyond tibial apex. Tarsal formula 5-5-5, protarsomeres 1-4 each ventrally with two pairs of distinctly modified spatulate setae, mesotarsomeres 1-4 possibly slightly so modified, metatarsomeres with only unmodified setae; tarsal claws equal (Fig. 1A and D).

Abdomen. Sternites III-VIII visible, male genital segment $(\mathrm{IX}+\mathrm{X})$ partly visible; sternite IX with 2 long stout apical setae.

Etymology. The generic name Duocalcar, of neuter gender, is formed from the Latin duo- meaning "two" plus calcar meaning "spur," alluding to the two distinctive projections on each hind leg, at the trochanteral apex and near the tibial apex.

\section{Duocalcar geminum Peris and Thayer sp. nov.}

Holotype. IGR.ARC-370.10, complete specimen, male, preserved in a piece of fully opaque amber in syninclusion with the paratype and other arthropods (see Material). Holotype imaged by synchrotron microtomography (=scan A018_c); deposited in amber collection of Geological Department of University Rennes 1 (France). Paratype. IGR.ARC-370.6, complete specimen, male, preserved in a piece of fully opaque amber in syninclusion with the holotype and other arthropods (see Material). Paratype imaged by 


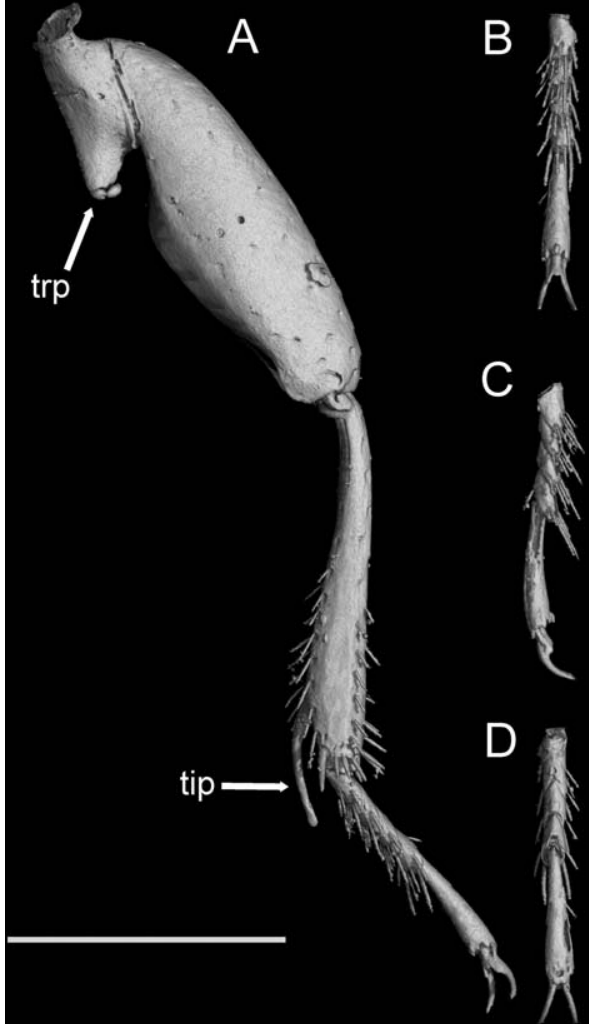

Fig. 3. D. geminum, holotype, left metaleg (A) anterior; (B) tarsus, ventral; (C) tarsus, lateral; (D) tarsus, dorsal. Scale bar $=200 \mu \mathrm{m}$. Abbreviations: tip, tibial subapical projection; trp, trochanteral apical projection.

synchrotron microtomography (=scan A018_g); deposited in amber collection of Geological Department of University Rennes 1 (France).
Type Locality and Horizon. Font-de-Benon quarry at Archingeay-Les Nouillers (Charente-Maritime, France). The piece was found in lithological level A1sl-A sensu Perrichot et al. (2010); mid-Cretaceous, latest Albian in age.

Diagnosis. As for the genus.

Description. Male. Body. Length (sum of separate measurements of head, thorax, and abdomen): 2.16 mm (holotype), $1.94 \mathrm{~mm}$ (paratype); maximum span of length as is: $1.43 \mathrm{~mm}$ (holotype), $1.57 \mathrm{~mm}$ (paratype); maximum body width: $0.71 \mathrm{~mm}$ (holotype), 0.64 $\mathrm{mm}$ (paratype); ratio of full body length to greatest width 3.04 (holotype), 3.03 (paratype).

Head. Eyes large, with medium-sized facets; frons and clypeus not elevated; frontoclypeal suture not differentiated, clypeus apically truncate, labrum inserted below clypeus, about as wide as apical margin of clypeus; labrum medially emarginate, with rounded apical margins. Maxillary palpomere 1 shorter than 2 , palpomere 2 narrower basally than apically, subequal in length to palpomere 4 , obliquely truncate apically; palpomere 3 roughly quadrate, 0.3 times length of and similar width to palpomere 2; palpomere 4 parallel-sided, slightly narrower and 3 times longer than palpomere 3. Labial palpomeres 1-3 roughly parallel-sided, 3 slightly longer than 1 and $\approx 1.5$ times as long as 2 . Gular sutures separated at closest point by about length of maxillary palpomere 4. Antennomeres 6-11 increasing in width, 7-11 forming a loose club (Fig. 4C-F); antennomere 1 longest, 2.3 times as long as wide and 1.5 times as long as antennomere 2; antennomere 2 ovate, its basal insertion in antennomere 1 very wide, clearly visible, antennomere 2 widest at two thirds from base, similar in width to antennomere 1; antennomere 30.8 times as long as antennomere 2, narrow basally, width increasing apicad, maximum width 0.4

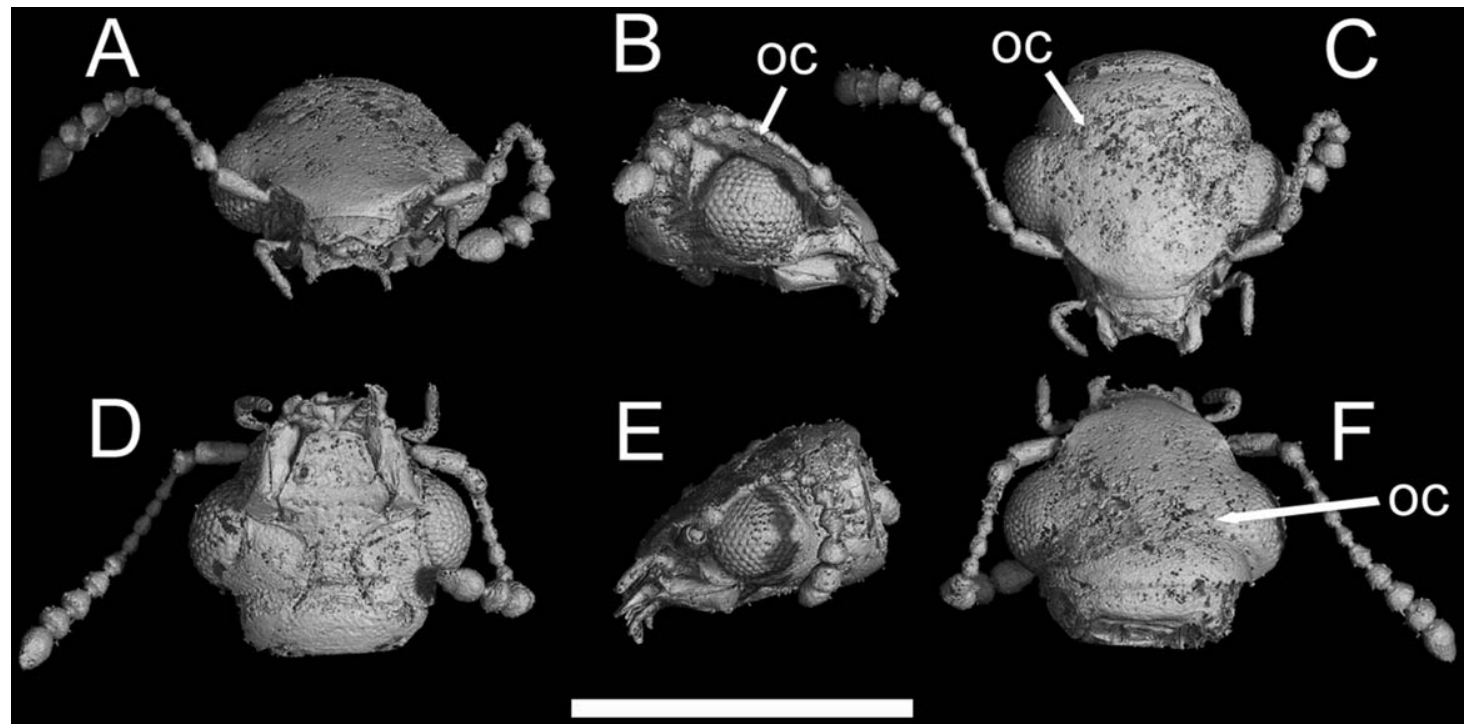

Fig. 4. D. geminum, paratype, head (A) anterodorsal; (B) right lateral; (C) dorsal; (D) ventral; (E) left lateral; (F) posterodorsal. Scale bar $=500 \mu \mathrm{m}$. Abbreviation: oc, ocellus. 
times that of antennomere 2; antennomeres 4-6 each a little shorter and wider than preceding, 0.7 times length and 1.1 times width of antennomere 3; antennomere 7 quadrate, 1.3 times as wide and 1.1 times as long as antennomere 6; antennomeres 8-10 quadrate to transverse, each 1.3 times wider than the preceding one, 8-9 about same length; antennomere 11 longer than each of 2-10,0.8 times length and 1.4 times width of antennomere 1 , similar in width to antennomere 9, apex acute, narrower than base.

Prothorax. Length $0.41 \mathrm{~mm}$, maximum width 0.58 $\mathrm{mm}$ (holotype), $0.57 \mathrm{~mm}$ (paratype); prothorax $\approx 1.4$ times as wide as long, widest and obtusely angulate at middle of lateral margins; pronotum with anterior angles hidden in dorsal view, forming approximately $90^{\circ}$ angle in lateral view, posterior angles slightly obtuse, posterior margin more or less straight; base of prothorax slightly narrower than across bases of elytra. Pronotal hypomeron and its postcoxal process (Fig. 1B) well-developed; pronotosternal suture distinct (in holotype, Fig. 1B, less so in paratype); prosternum coarsely sculptured, seemingly impunctate, length before procoxae as long as procoxal length; external part of trochantin about half as long as procoxa, pointed laterally and with keel along middle; prosternal process short, 0.5 times as long as procoxae, sharp apically. Mesocoxae separated by 0.3 times middle width of a mesocoxa; mesoventral process extending about half mesocoxal length, overlapping metaventral process, apically rounded. Metaventrite 1.3 times as long as mesoventrite; metepisternum roughly triangular, as long as metaventrite, margin between them strongly evident; posterior margin of metaventrite more or less transverse, metakatepisternal suture visible anterior to it. Metacoxa with vertical posterior face, excavate near apex, covering base of metafemur in repose.

Elytra. Length $0.71 \mathrm{~mm}$ (holotype), $0.72 \mathrm{~mm}$ (paratype); combined elytral width $0.71 \mathrm{~mm}$ (holotype), 0.63 (paratype); elytra 1.74 (holotype) or 1.79 (paratype) times as long as pronotum; with parallel margins. Anterior elytral angles straight, lateral margins carinate, sutural margins apparently with typical interlocking ridges, posterolateral angles rounded. Wings fully developed (Fig. 2C).

Legs. All legs of similar length, femora widest at middle. Tibiae nearly as long as femora, wider apically than basally, with broad setae in rows along them; metatibial subapical spur 0.3 times as long as tibia. Protarsi 0.6 times as long as corresponding tibiae, 0.6 and 0.7 in meso- and metatarsi, tarsomeres 1-4 slightly oblique in lateral view, of similar shape and size, extending ventrad slightly and with long setae on the ventral extension; setae on protarsi ( 2 pairs per tarsomere) flattened and greatly enlarged apically as spatulate (presumably tenent) setae (Fig. 1A and D), those on mesotarsi possibly weakly modified (Fig. 1A), those on metatarsi simple (Figs. 1A and 3); metatarsomere 5 as long as 1-4 together, apically truncate, with two equal simple claws.
Abdomen. Segments III to VIII decreasing successively in width. Abdominal segment III covered dorsally by elytra, 1.6 times as long as segment IV; abdominal segments IV to VI similar in length; segment VII 1.5 times as long as VI; segment VIII 1.7 times as long as segment VII, strongly narrowed to truncate apex. Segments III-VII each with one pair of paratergites laterally, spiracles in lateral margins of tergites III-VII, placement on segment VIII not clear. Sternite VIII apex broadly emarginate medially, with an apicolateral tooth on each side; medially impressed over apical half, with tooth on each side of impression (Fig. $2 \mathrm{E}$ ). Segment IX with two broad laterotergites ventrally overlapping narrow sternite IX, latter with 2 apical setae slightly longer than segment VIII; boundary between tergites IX and X not discernible, probably hidden within segment VIII.

Female. Unknown.

Etymology. The specific epithet geminum is a Latin adjective meaning "twin-born," in reference to the discovery of both specimens in the same piece of amber.

\section{Discussion}

Placement of the new genus in Omaliinae is supported by several features. First is the presence of ocelli (seen as raised bumps) between the posterior margins of the eyes (Newton et al. 2000). Although both ocelli are not clear in either specimen at the same time, one ocellus can be seen in each specimen. Numerous other features preclude placement in any of the other staphylinid groups known to have a pair of ocelli (Microsilphinae Crowson, Glypholomatinae Jeannel, and Neophoninae Fauvel). Newton and Thayer (1995) described Omaliinae as having a more or less ovoid body shape, large solid prohypomeral postcoxal processes, relatively long elytra, contiguous and broad metacoxae, and each abdominal segment with one pair of paratergites; all these characteristics are present in D. geminum. Although the spiracles of abdominal segment VIII are not visible in the new taxon, it has none of the specialized antennal or mouthpart features of Microsilphinae, which lack spiracles on VIII (Newton and Thayer 1995). Another feature found in winged Omaliinae that is not visible in Duocalcar is the presence of paired wing-folding patches of minute spicules on one or more abdominal tergites (Hammond 1979, Newton and Thayer 1995); the absence of these microstructures in the reconstruction could be an artifact. The presence of 1) maxillary palpomere 4 as wide as 3,2 ) spines on the outer surface of the protibia, 3) well-developed spiracles on segments III-VII, and 4) brick-wall-like sclerites on abdominal intersegmental membranes III-VII and the absence of an external transverse connection between the gular sutures contradict placement in Proteininae Erichson (maxillary palpomere 4 narrower than 3, no preapical protibial spines, spiracles atrophied on segments IV-VI, no such sclerites; connection present; Newton and Thayer 1995), some genera of which resemble the 
new genus. Within Omaliinae, based on general appearance the new genus could be mistaken for Eusphalerini Hatch, but tarsomeres 1-4 are not widened as occurs on all legs of Eusphalerum Kraatz (Coleoptera: Staphylinidae), the single known genus in the tribe. Having maxillary palpomere 4 usually as wide as 3 , tarsomeres 1-4 together shorter than tarsomere 5, and antennomeres 7-10 quadrate to transverse, forming a loose club, argues for placement in Omaliini (Newton et al. 2000). A number of potentially derived features of Omaliini unfortunately cannot be assessed in the fossils: anterior tentorial arms reduced; maximum of 1 preapical tooth on each mandible; presence (in winged taxa) of a seta-rimmed transverse groove posteriorly on tergite III (Hammond 1979); and female with a sclerotized (usually 2-chambered) spermatheca (M.K.T., unpublished data). Empodial setae are not evident in the reconstructions, but that may be an artifact of preservation, resolution, or both.

Within Omaliini, Duocalcar resembles or shares similar features with the extant genera Hapalaraea Thomson, Acrolocha Thomson, Phyllodrepa Thomson, Xanthonomus Bernhauer, Omaliopsis Jeannel, and Acruliopsis Zerche. Duocalcar is less convex than Hapalaraea, lacks the very narrow third antennomere base found in both that genus and Acrolocha, and has the pronotal lateral margins angulate instead of evenly rounded. It is intriguing that some species of Hapalaraea have modifications of the male metatibiae, although those are laminar rather than cylindrical projections (K. T. Eldredge and M.K.T., in preparation), and of the male metatrochanters (somewhat different in form). Some species of Acrolocha also share with Duocalcar the possession of a sharp projection on the male metatrochanter (Steel 1957), but they differ from the new genus in having distinct paramedian and sublateral pronotal impressions. Duocalcar shares with Phyllodrepa the pronotum with right-angled anterior corners (visible in lateral view of Duocalcar, Figs. 1A and $\mathrm{D}$ and $2 \mathrm{~B}, \mathrm{E}$ ) and long ventral tarsal setae, but Phyllodrepa has the gular sutures closer, almost in contact, and the elytral punctures not arranged in rows. (Phyllodrepa and Hapalaraea differ from each other in having versus lacking visible dorsal tentorial pits; those pits are not discernible in the images of Duocalcar, but that may be an artifact: they are not always evident in scanning electron micrographs.) The protarsal setae of Duocalcar - an extreme version of a modification found in males of numerous generaare reminiscent of those of Xanthonomus, but in that genus (allied to Phloeonomus Heer) the modified setae occur on all tarsi, maxillary palpomere 4 is distinctly narrower than 3, and abdominal segments III-VI lack paratergites (Steel 1955). The tooth-like projections on sternite VIII in Duocalcar - highly likely to be male secondary sexual characters - bear some resemblance to the single pair characteristic of male Omaliopsis spp. (M.K.T., in preparation), but are in a different position. Omaliopsis spp. also differ in having tarsomeres 1-4 much shorter than 5 and the pronotum bearing paramedian and posterolateral impressions instead of being evenly convex. Duocalcar resembles Acruliopsis in the convex disk of the pronotum and the obtusely angulate lateral pronotal margins, but Acruliopsis species have the frons and vertex of the head distinctly elevated above the eyes (like a few other genera), medium-sized or small eyes, a small scutellum, and the elytra apically truncate in a straight line. There are also characters of the male genitalia that distinguish the extant genera mentioned, but unfortunately it is not possible to assess those in the available reconstructions of Duocalcar.

As alluded to above, the modifications in Duocalcar of the protarsal (and perhaps mesotarsal) ventral setae, metatrochanters and tibiae, and sternite VIII are similar to male secondary sexual characters found in several different extant genera of Omaliini. Both specimens of Duocalcar are males, so it seems likely that these features are likewise male-only characters, but confirmation or refutation of that will require discovery of female specimens.

Most extant species of Omaliini are associated with mesic temperate forest biomes, and many of them live in the litter layer, though others live subcortically in logs or on fungi. As far as known, these are primarily predaceous or saprophagous, though some could be mycophagous. A few-including many of the relatively scarce tropical representatives-are pollen feeders found in flowers (Newton et al. 2000). Coniferous forests support a significant proportion of the Omaliini in temperate areas of both northern (Pinaceae- or Cupressaceae-dominated) and southern (Podocarpaceae- or Araucariaceae-dominated) hemispheres. The discovery of $D$. geminum in the araucariacean-derived Cretaceous amber of Charentes (Perrichot et al. 2007, 2010) suggests that the association of Omaliini with coniferous forests is at least 100 million years old.

\section{Conclusions}

D. geminum is the first Omaliinae described from any amber, increasing the minimum age of Omaliini to $\approx 100$ million years, from Eocene to latest Albian. The new taxon has what are probably male secondary sexual characters that resemble those found individually in different extant genera of Omaliini. The discovery and description were made possible with the use of the propagation phase-contrast X-ray synchrotron imaging technique, which allows astonishingly detailed study of otherwise invisible specimens in opaque amber.

\section{Acknowledgments}

We are grateful to Michael S. Engel (Natural History Museum, Kansas, USA) for providing support to this investigation, hosting D.P. at the University of Kansas, and offering the use of the collections there for comparisons. We also thank Alfred F. Newton (Field Museum of Natural History, Illinois, USA) for allowing M.K.T. free access to his unpublished Staphyliniformia database. Carmen Soriano (ESRF, France) assisted with the synchrotron illus- 
trations. We thank two anonymous reviewers and editor M. S. Caterino for their comments. This work is part of the Ph.D. dissertation of D.P., supported by an Formación de Profesor Universitario (FPU) grant from the Spanish Ministry of Education. Partial support for this work was from the French National Research Agency grant Ambres Crétacés de France (AMBRACE). This work was supported by the ESRF through its in-house research program on beamline ID19 in collaboration with Paul Tafforeau (ESRF, France). It is also a contribution to projects Interrvie Nouvelles Variétés d'Ambres Crétacés de France (NOVAMBRE) 2 from the French Centre National de la Recherché Scientifique (CNRS) -Institut National des Sciences de l'Univers, and to project CGL2011-23948, "The Cretaceous amber of Spain: A multidisciplinary study II," from the Spanish Ministry of Economy and Competitiveness.

\section{References Cited}

Bouchard, P., Y. Bousquet, A. E. Davies, M. A. AlonsoZarazaga, J. F. Lawrence, C. H. Lyal, A. F. Newton, C.A.M. Reid, M. Schmitt, S. A. Slipinski, et al. 2011. Family-group names in Coleoptera (Insecta). Zookeys 88: $1-972$.

Cai, C., and D. Huang. 2013. Sinanthobium daohugouense, a tiny new omaliine rove beetle (Coleoptera: Staphylinidae) from the Middle Jurassic of China. Can. Entomol. 145: $1-5$.

Chatzimanolis, S., D. A. Grimaldi, M. S. Engel, and N. C. Fraser. 2012. Leehermania prorova, the earliest staphyliniform beetle, from the Late Triassic of Virginia (Coleoptera: Staphylinidae). Am. Mus. Novit. 3761: 1-28.

Dejax, J., and E. Masure. 2005. Analyse palynologique de l'argile lignitifère à ambre de l'Albien terminal d'Archingeay (Charente-Maritime, France). C. R. Palevol. 4: 53-66.

Girard, V., A. R. Schmidt, S. Struwe, V. Perrichot, G. Breton, and D. Néraudeau. 2009. Taphonomy and palaeoecology of mid-Cretaceous amber-preserved microorganisms from southwestern France. Geodiversitas 31: 152-163.

Gomez, B., C. Coiffard, E. Dépré, V. Daviero-Gomez, and D. Néraudeau. 2008. Diversity and histology of a plant litter bed from the Cenomanian of Archingeay-Les Nouillers (southwestern France). C. R. Palevol. 7: 135-144.

Grebennikov, V. V., and A. F. Newton. 2009. Good-bye Scydmaenidae, or why the ant-like stone beetles should become megadiverse Staphylinidae sensu latissimo (Coleoptera). Eur. J. Entomol. 106: 275-301.

Hammond, P. M. 1979. Wing-folding mechanisms of beetles, with special reference to investigations of Adephagan phylogeny (Coleoptera), pp. 113-180. In T. L. Erwin, G. E. Ball, and D. R. Whitehead (eds.), Carabid Beetles: Their Evolution, Natural History, and Classification. W. Junk, Dordrecht, The Netherlands.

Lak, M., D. Néraudeau, A. Nel, P. Cloetens, V. Perrichot, and P. Tafforeau. 2008. Phase contrast X-ray synchrotron imaging: opening access to fossil inclusions in opaque amber. Microsc. Microanal. 14: 251-259.

Lawrence, J. F., R. G. Beutel, R.A.B. Leschen, and A. Ślipiński. 2010. Glossary of morphological terms, pp. 9-20. In R.A.B. Leschen, R. G. Beutel and J. F. Lawrence (eds.), Handbook of Zoology, Arthropoda: Insecta. Coleoptera, vol. 2, Morphology and Systematics (Elateroidea, Bostrichiformia, Cucujiformia partim). Walter de Gruyter, Berlin, Germany and New York.

Néraudeau, D., V. Perrichot, J. Dejax, E. Masure, A. Nel., M. Philippe, P. Moreau, F. Guillocheau, and T. Guyot. 2002.
Un nouveau gisement à ambre insectifère et à végétaux (Albien terminal probable): Archingeay (Charente-Maritime, France). Geobios 35: 233-240.

Newton, A. F., and M. K. Thayer. 1995. Protopselaphinae new subfamily for Protopselaphus new genus from Malaysia, with a phylogenetic analysis and review of the Omaliine Group of Staphylinidae including Pselaphidae, pp. 219-320. In J. Pakaluk and S. A. Slipinski (eds.), Biology, phylogeny, and classification of Coleoptera: papers celebrating the 80th birthday of Roy A. Crowson. Muzeum i Instytut Zoologii PAN, Warsaw, Poland.

Newton, A. F., M. K. Thayer, J. S. Ashe, and D. S. Chandler. 2000. Staphylinidae Latreille, 1802, pp. 272-418. In R. H. Jr. Arnett and M. C. Thomas (eds.), American Beetles, vol. 1, Archostemata, Myxophaga, Adephaga, Polyphaga: Staphyliniformia. CRC LLC, Boca Raton, FL.

Peris, D., S. R. Davis, M. S. Engel, and X. Delclòs. 2014a. An evolutionary history embedded in amber: reflection of the Mesozoic shift in weevil-dominated (Coleoptera: Curculionoidea) faunas. Zool. J. Linnean Soc. 171: 534553.

Peris, D., X. Delclòs, C. Soriano, and V. Perrichot. 2014b. The earliest occurrence and remarkable stasis of the family Bostrichidae (Coleoptera: Polyphaga) in Cretaceous Charentes amber. Palaeontologica Electronica 17.1.14A.

Peris, D., J. Kolibáč, and X. Delclòs. 2014c. Cretamerus vulloi gen. et sp. nov., the oldest bark-gnawing beetle (Coleoptera: Trogossitidae) from the Cretaceous amber. J. Syst. Palaeontol. (doi: 10.1080/14772019.2013.853108).

Perrichot, V., A. Nel, and D. Néraudeau. 2004. Two new wedge-shaped beetles in Albo-Cenomanian ambers of France (Coleoptera: Ripiphoridae: Ripiphorinae). Eur. J. Entomol. 101: 577-581.

Perrichot, V., D. Néraudeau, A. Nel, and G. de Ploëg. 2007. A reassessment of the Cretaceous amber deposits from France and their palaeontological significance. Afr. Invertebr. 48: 213-227.

Perrichot, V., D. Néraudeau, and P. Tafforeau. 2010. Charentese amber, pp. 192-207. In D. Penney (ed.), Biodiversity of fossils in amber from the major world deposits. Siri Scientific Press, Manchester.

Perrichot, V., J. Ortega-Blanco, R. C. McKellar, X. Delclòs, D. Azar, A. Nel, P. Tafforeau, and M. S. Engel. 2011. New and revised maimetshid wasps from Cretaceous ambers (Hymenoptera, Maimetshidae). ZooKeys 130: 421- 453 .

Soriano, C. 2009. First record of the family Belidae (Insecta, Coleoptera) in amber. New genus and species from the uppermost Albian amber of France. Geodiversitas 31: 99-104.

Soriano, C., M. Archer, D. Azar, P. Creaser, X. Delclòs, H. Godthelp, S. Hand, A. Jones, A. Nel, D. Néraudeau, et al. 2010. Synchrotron $X-$ Ray imaging of inclusions in amber. C. R. Palevol. 9: 361-368.

Soriano, C., D. Pollock, D. Néraudeau, A. Nel, and P. Tafforeau. 2014. First fossil record of polypore fungus beetles from Lower Cretaceous amber of France. Acta Palaeontol. Pol. (doi: 10.4202/app.2012.0074).

Steel, W. O. 1955. Notes on the Omaliinae (Col., Staphylinidae). (7) The genus Xanthonomus Bernhauer. Entomol. Mon. Mag. 91: 275-278.

Steel, W. O. 1957. Notes on the Omaliinae (Col., Staphylinidae). (8) The genus Acrolocha Thomson. Entomol. Mon. Mag. 93: 157-164.

Tafforeau, P., R. Boistel, E. Boller, A. Bravin, M. Brunet, Y. Chaimanee, P. Cloetens, M. Feist, J. Hoszowska, J.-J. Jaeger, et al. 2006. Applications of X-ray synchrotron 
microtomography for non-destructive 3D studies of paleontological specimens. Appl. Phys. A. 83: 195-202. Thayer, M. K. 2005. Staphylinidae Latreille, 1802, pp. 296 344. In R. G. Beutel and R.A.B. Leschen (eds.), Handbook of Zoology, Arthropoda: Insecta. Coleoptera, vol. 1, Mor- phology and Systematics (Archostemata, Adephaga, Myxophaga, Polyphaga partim). Walter de Gruyter, Berlin, Germany and New York.

Received 19 March 2014; accepted 17 June 2014. 